\title{
In Search of Due Diligence Obligations in UN Peacekeeping Operations
}

\section{Identifying Standards for Accountability}

\author{
Nigel D. White* \\ University of Nottingham, School of Law, University Park, Nottingham, \\ United Kingdom \\ nigel.white@nottingham.ac.uk
}

\begin{abstract}
It is argued in this article that due diligence, grounded on positive duties under international human rights law, is a standard against which to measure the performance of UN peacekeeping forces. Its adoption by the UN will improve accountability, but in a controlled and principled way. A requirement that the UN act diligently to prevent human rights violations would not impose over-onerous obligations. For responsibility to be incurred an organisation must have clearly failed to take measures that were within its power to take. It is argued that the UN not only should be bound by norms of due diligence but is in fact bound by positive obligations derived from customary international human rights law. The development of some due diligence-type measures by the UN to prevent sexual abuse by peacekeepers and to protect civilians within areas of peacekeeper deployment, and the adoption of an explicit due diligence policy to delineate its relationship with non-UN security actors, are positive signs. However, the article demonstrates that the UN needs to further internalise and develop its due diligence obligations if it is to limit human rights violations committed under its watch. Furthermore, it needs to create accountability mechanisms to ensure that it develops the rather limited measures taken thus far, including provision for victims to be able to hold the organisation to account for failure to protect them from human rights violations. Only by accepting its responsibility and liability to such victims will be the UN be driven to improve its due diligence when mandating, preparing, training, deploying and directing peacekeeping operations.
\end{abstract}

* Professor of Public International Law and Director of Research, School of Law, University of Nottingham; Visiting Professor Graduate School of International Cooperation Studies, Kobe University, November 2019. 


\section{Keywords}

United Nations - peacekeeping - due diligence - responsibility - accountability

In a sense arguments over the immunity and accountability of the UN have obscured the ongoing uncertainty over the primary and secondary rules of international law applicable to the UN when undertaking peacekeeping. It is necessary to understand what violations of international law have been committed by the UN before any attempt is made to assess whether immunity should prevent access to justice before national courts and whether alternative methods of settlement are required.

Accountability generally improves in response to pressures exerted or released after or during crises or scandals. ${ }^{1}$ However, the UN seems to be inured to such pressures. Sexual abuse and exploitation (SEA) by peacekeepers continues as do failures to take adequate measures to protect civilians from violence in areas where peacekeepers are deployed. The UN has hidden behind its cloak of immunity when faced with mass claims arising from the genocide in Srebrenica and from the cholera epidemic in Haiti. Moreover, it has failed to stop the epidemic of SEA that runs across UN peacekeeping operation like an open sore. The scandals and crises attached to these human rights violations do not seem to have improved the UN's accountability. The fear of exposure to mass claims only partly explains the UN's continued reliance on absolute immunity as provided by the Convention on Privileges and Immunities 1946, and its reluctance to establish the type of claims commissions delivering nonjudicial redress promised in every peacekeeping status-of-forces-agreement (SOFA) but never delivered. ${ }^{2}$

\footnotetext{
** This article develops some of the themes found in Nigel D. White, 'Due Diligence, the UN and Peacekeeping' in Heike Krieger and Anne Peters (eds), Due Diligence in International Law (Oxford: Oxford University Press, forthcoming 2021).

1 Richard Mulgan, 'AwB and oil for food: some issues of accountability' in Jeremy Farrall and Kim Rubenstein (eds) Sanctions, Accountability and Governance in a Globalised World (Cambridge: Cambridge University Press, 2009), p. 334.

2 UN Doc. A/RES/45/594, 9 October 1990, para. 51.
} 


\section{Due Diligence as a Standard}

One solution to the lack of clarity in the primary and secondary rules applicable to the UN is to recognise that due diligence is applicable to the UN. In general, due diligence has become a short hand reference to a set of criteria for assessing the level of care' provide by state authorities, ${ }^{3}$ and it is argued here other international legal persons whose actions impact upon individuals. More specifically this signifies that the UN should take care to ensure that those actors it has mandated and over whom it exercises authority do not act in a way that causes damage, injury or loss, or fail to act to prevent damage, injury or loss, especially when that is a result of their internationally wrongful conduct.

Due diligence obligations are found in various areas of international law, ${ }^{4}$ but are particularly developed in international human rights law as a result of the positive obligations placed on states to ensure the protection of human rights of individuals within their jurisdiction. Under international human rights law a state's 'obligations in relation to the actions of third parties are often expressed in terms of due diligence', meaning that the state can be 'held liable for human rights violations caused by a third party where the state has failed to exercise due diligence to prevent the violation or to respond as required.' ${ }^{5}$ Extending this standard to the UN entails accepting the premise that the UN is bound by customary international law and that positive obligations are found in customary human rights law or, indeed, are emerging as customary norms, given that the $\mathrm{UN}$ is not a party to the human rights treaties which contain such positive duties. These issues will be returned to. Furthermore, extending due diligence to the $\mathrm{UN}$ as a legal obligation also depends upon whether the UN exerts sufficient authority and control in a host state through its peacekeeping force for human rights obligations to attach to it. On the latter point, the Human Rights Committee felt that the obligations of troop contributing nations (TCNs) to ensure the human rights of individuals within their power or control applied extraterritorially when their troops formed part of a peacekeeping mission. ${ }^{6}$ These are treaty obligations of TCNs drawn from the International Covenant on Civil and Political Rights, but it is argued that

3 Joanna Kulesza, Due Diligence in International Law (Leiden: Nijhoff, 2016), p. 1.

4 Ibid, p. 11 for the further argument that due diligence is 'a principle of international law'.

5 ILA Study Group on Due Diligence in International Law, 'Second Report', 12 July 2016, p. 32, citing Velasquez Rodriguez Case, Judgment of July 29, 1988, Inter-Am.Ct.H.R. (Ser. C) No. 4 (1988), para. 172.

6 Human Rights Committee General Comment 31, 'Nature of the General Legal Obligation on State Parties to the Covenant', CCPR/C/21/Rev.1/Add.13 (2004), para. 10. 
their customary equivalents apply to the $\mathrm{UN}$ as an international legal person having rights and duties under international law and exercising authority and control over individuals through its peacekeepers. ${ }^{7}$

This would mean that if the UN does not act diligently to prevent human rights violations when it has the power to do so then it would be responsible and accountable to those suffering harms as a result of those violations. If the UN does not waive its immunity before domestic courts when faced with claims arising from its failures, it will have to establish alternative methods of settlement. Placing its conduct within a human rights due diligence paradigm will, it is argued, put genuine pressure on the UN either to reform itself regarding immunity and dispute settlement or face the consequences of its intransigence. If the UN remains unchanged then the possibility arises of domestic courts and host governments being less amenable to its stance on immunity. Host states often desperately need UN assistance but not at any cost. It is argued that the adoption of due diligence as a standard against which to measure the performance of UN peacekeeping forces will improve accountability, but in a controlled and principled way. ${ }^{8}$ A requirement that the UN act diligently to prevent harm being caused by human rights violations would not impose over-onerous obligations. For responsibility to be incurred, it must be demonstrated that the UN had 'manifestly failed to take all measures' that were 'within its power' to take. ${ }^{9}$ It is argued that the UN not only should be bound by norms of due diligence but is in fact bound, although disputes about the nature and extent of such obligations remain to be fully resolved. Nevertheless, reflecting its position as a leading human rights norm creator and promotor, the UN needs to internalise these norms as a first step towards empowering victims to hold the organisation to account if it manifestly fails to protect them from human rights violations when it had the power to do so.

\section{$3 \quad$ An Appropriate Normative Framework for Peacekeeping}

Due diligence is argued to be an appropriate way to view the UN's human rights obligations. This is because the UN itself does not directly perform

7 Terry D. Gill, Dieter Fleck, William H. Boothby and Alfons Vanheusden, Leuven Manual on the International Law Applicable to Peace Operations (Cambridge: Cambridge University Press, 2017), p. 76 , p. 78.

8 For ideas for the development of an accountability framework for peacekeeping operations see the contribution of Norihito Samata in this issue.

9 ILA Study Group, supra note 5, p. 8, citing, inter alia, Application of the Convention on the Prevention and Punishment of the Crime of Genocide (Bosnia and Herzegovina $v$ Serbia and Montenegro) Judgment (2007) ICJ Reports, p. 43, para. 430. 
peacekeeping but relies on forms of 'outsourcing' to states and occasionally, for restricted purposes, to private security contractors. ${ }^{10}$ Indeed, given that characteristic of peacekeeping it can be argued that the UN's human rights obligations under customary international law 'are best operationalized in a more general fashion, though the prism of due diligence.11 The UN, unlike states, does 'not possess a general competence, ${ }^{12}$ meaning that 'the precise catalogue of rights and duties is ... impossible to list in advance. ${ }^{13}$ This proposition applies within specific regimes, including human rights law. According to Quenivet, 'customary human rights only applies to those UN activities that are related to its purposes and functions and have an impact on human rights. ${ }^{14}$ The UN exercises certain public powers (of arrest, detention, and the use of force) alongside host governments and its peacekeepers may have varying degrees of control over parts of the country and over individuals within it. ${ }^{15}$ Furthermore, the UN has a significant degree of authority over peacekeepers. ${ }^{16}$ In these circumstances duties of due diligence are an appropriate way of understanding the application of human rights law to UN peacekeeping operations. In a sense due diligence under human rights law in not an additional element to the UN's 'normal' human rights duties, it seeks to define the core human rights duties applicable to operational organisations such as the UN.

It is not possible to say that when a UN peacekeeper acts their actions automatically are actions of the UN. Peacekeepers are not agents of the UN, they remain agents of the state and part of a state organ of the troop contributing

10 Mirko Sossai, 'The Privatisation of the Core Business of UN Peacekeeping Operations: Any Legal Limit?', International Community Law Review, vol. 16, 2014, p. 405. On the more widespread UN practice of outsourcing non-security functions to contractors see the contribution by Martina Buscemi in this issue.

11 Ellen Campbell el al, 'Due Diligence Obligations of International Organizations under International Law', New York University Journal of International Law and Politics, vol. 50, 2018, p. 558, citing Andrew Clapham, Human Rights Obligations of Non-State Actors (Oxford: Oxford University Press, 2006), p. 151.

12 Noelle Quenivet, 'Binding the United Nations to Customary (Human Rights) Law', International Organizations Law Review, vol. 17, 2020, p. 399.

13 Malcolm Shaw, International Law (Cambridge: Cambridge University Press, $7^{\text {th }}$ edn, 2014), p. 192.

14 Quenivet, supra note 12, p. 400.

15 Gill, Fleck, Boothby and Vanheusdan, supra note 7, pp. 267-8.

16 'Operational authority' has been defined by the UN as ' $[t]$ he authority transferred by the member states to the United Nations to use the operational capabilities of their national military contingents ... to undertake mandated missions and tasks', which in peacekeeping operations 'is vested in the Secretary-General, under the authority of the Security Council' involving 'the full authority to issue operational directives' - UNDPKO and DFS, 'Authority, Command and Control in United Nations Peacekeeping Operations', 15 February 2008 , para. 7 . 
nation (TCN) ${ }^{17}$ The rules on attribution of conduct agreed by the International Law Commission (ILC) reflect this. In the Articles on the Responsibility of International Organisations (ARIO) 2011, the preferred test for peacekeeping operations, according to the ILC, is Article $7,{ }^{18}$ which states that the conduct of an organ of a state, in this case the military, placed at the disposal of the UN shall be considered an act of the UN if the organisation 'exercises effective control over that conduct.' 19 The ILC stated that this was applicable to peacekeeping forces signifying that the TCN remains responsible for the conduct of its soldiers deployed as part of a UN peacekeeping force rather than the UN, unless it is shown that the UN is in effective control of the conduct in question. However, there is no explanation of why Article 6 of ARIO would not be an equally valid basis for attribution of conduct given that it provides that the conduct of organs of the organisation are acts of the organisation. ${ }^{20}$ The UN views peacekeeping forces as subsidiary organs, indeed has indicated that on this basis it accepts responsibility for wrongful conduct committed by peacekeeping forces during the course of their functions. ${ }^{21}$ This suggests that the ILC rules do not capture UN practice, nor do they necessarily reflect the law. ${ }^{22}$ A number of commentators have suggested that a more accurate starting point for attribution is a presumption that the conduct of a peacekeeping force is attributable to the organisation on the basis that it is a subsidiary organ of the UN. However, this is a presumption that can be rebutted by evidence that the TCN remains in effective control of the wrongful conduct in question. ${ }^{23}$

17 Gill, Fleck, Boothby and Vanheusdan, supra note 7, p. 77.

18 United Nations, ILC Report of the Work of the Sixty-Third Session, UN Doc. A/66/10, 23 April-3 June and 4 July-12 August 2011, p. 90.

19 Articles on the Responsibility of International Organisations 2011 (ARIO), UN Doc. A/66/10, Article 7 .

$20 \quad$ Ibid, Article 6.

21 UN Secretariat - 'as a subsidiary organ of the United Nations, an act of a peacekeeping force is, in principle, imputable to the Organization, and if committed in violation of an international obligation entails the international responsibility of the Organization and its liability in compensation' - UN Doc. A/CN.4/545 (2004), para. 17.

22 Gill, Fleck, Boothby and Vanheusden, supra note 7, p. 279: '[I]t is doubtful whether ARIO's attempt to prescribe a single test of attribution applicable to all types of Peace Operations in the form of article 7 ARIO reflects the law as it currently stands. While the test of effective control is appropriate in some circumstances, in other priority should be given to the institutional paradigm of attribution'.

23 Aurel Sari, 'UN Peacekeeping Operations and Article 7 ARIO: The Missing Link', International Organizations Law Review, vol. 9, 2012, p. 78; Paolo Palchetti, 'International Responsibility for Conduct of UN Peace-keeping Forces: The Question of Attribution' in Paolo Palchetti et al (eds), Refining Human Rights Obligations in Conflict Situations (The Hague: Asser, 2014) p. 24; Yohei Okada, 'Effective control test at the interface between the law of 
Viewing a peacekeeping operation in principle as a subsidiary organ of the UN does not override the fact that such an operation is made up of separate state organs in the form of contingents from TCNs, each operating within a defined area of deployment, and each with their own command and disciplinary structures. ${ }^{24}$ Although the UN has 'operational authority' over peacekeeping through the Secretary General and Force Commander, ${ }^{25}$ this does not guarantee effective command and control of the conduct of peacekeepers on the ground. Evidence that the use of the so-called 'Red Card' whereby a TCN commander may refuse to follow orders issued by the UN Force Commander after consulting with his government is readily found. ${ }^{26}$ Given the proscriptive nature of a state's military law and the hierarchical nature of national command structures, it can be presumed that soldiers are operating under national command and national rules of engagement (RoE) for at least some of the time while serving in international military operations, including blue-helmeted $\mathrm{UN}$ peacekeeping operations, ${ }^{27}$ despite the development of clearer RoE at UN level. ${ }^{28}$

This leads to an accountability gap or, more accurately, an accountability dilemma between the UN's authority and overall command over peacekeeping operations and the TCNs' day-to-day control of peacekeepers. The dilemma is that the UN ought to have human rights duties and not just the TCN for practical and ethical as well as legal reasons. If it were just TCNs that bore responsibility for human rights violations by their troops while on peacekeeping duty, then TCNS would either operate mostly outside the UN command structure or would cease to contribute troops for fear of liability. This dilemma can be

international responsibility and the law of international organizations: Managing concerns over the attribution of UN peacekeepers' conduct to troop-contributing nations', Leiden Journal of International Law, vol. 32, 2019, p. 28o; Gill, Fleck, Boothby and Vanheusden, supra note 7, p. 279. See further the contribution of Yohei Okada in this issue.

24 Gill, Fleck, Boothby and Vanheusden, supra note 7, p. 77.

25 UNDPKO and DFS, supra note 16.

26 Ramesh Thakur and Dipankar Banerjee, 'India: Democratic, Poor, Internationalist' in Charlotte Ku and Harold Jacobson (eds), Democratic Accountability and the Use of Force in International Law (Cambridge: Cambridge University Press, 2003) 198; Dale Stephens, 'The Lawful Use of Force by Peacekeeping Forces: The Tactical Imperative', International Peacekeeping, vol. 12, 2005, p. 160.

27 Peter Rowe, 'The United Nations Rules of Engagement and the British Soldier in Bosnia', International and Comparative Law Quarterly, vol. 43, 1994, p. 954.

28 Rob McLoughlin, 'Some Rules of Engagement Legacies of the 1999 Report of the Independent Inquiry into the Actions of the United Nations during the 1994 Genocide in Rwanda', Journal of International Peacekeeping, vol. 22, 2018, pp. 311-12, discussing the 'Guidelines for the Development of Rules of Engagement (ков) for United Nations Peacekeeping Operations', 15 May 2002 (MD/FGS/0220.0001). 
addressed by arguing that the UN has due diligence obligations in regard to the conduct of peacekeepers it has set in train. Peacekeepers remain soldiers of their sending states but they are also peacekeepers acting for the $\mathrm{UN}^{29}$ meaning that the UN should be diligent to ensure that peacekeepers operate within an institutional and procedural framework that includes respect for, and protection of, the human rights of the civilian population of the host state. In this way due diligence can fill a gap in an "era of "privatized" international relations', ${ }^{30}$ because although the UN may not effectively control all of the activities carried out under its authority, it still owes a duty of due diligence to those affected by such activities.

Although at this stage this remains an abstract contention - to the effect that the UN, as an international actor deploying armed forces with the concomitant potential for both harm and for preventing harm, ought to be bound by obligations of due diligence in a moral sense - it will be argued below that the UN is also bound in a legal sense. The purpose of this section is to establish that due diligence provides an appropriate standard against which to judge the UN in performing its peacekeeping function. The application, acceptance, and implementation of human rights due diligence obligations in UN peacekeeping operations are considered in section 5 below. There is limited and uneven evidence of the development of standards and measures by the UN that would fit the meaning and purpose of due diligence, although there are very few instances of due diligence being used as a term within the UN (with the exception of the quite narrowly conceived Human Rights Due Diligence Policy adopted in relation to non-UN security forces). ${ }^{31}$ Nonetheless, the contention in this article is that due diligence obligations are applicable to the UN as primary rules of international law supported by secondary rules of responsibility. ${ }^{32}$ This position is developed in the following section.

While the above section established that the conditions are present whereby due diligence obligations can and should apply to the UN, it remains to be established that the UN has duties under international law, including positive

29 Gill, Fleck, Boothby and Vanheusden, supra note 7, p. 77.

3o Kulesza, supra note 3, p. 1.

31 'Human rights due diligence policy on United Nations support to non-United Nations security forces', UN Doc. A/67/775-S/2013/110, 5 March 2013.

32 Timo Koivurova, 'Due Diligence' in Rüdiger Wolfrum (ed), Max Planck Encyclopaedia of Public International Law (Oxford: Oxford University Press, 2010). 
obligations under human rights law. Jan Klabbers for one is sceptical about whether the UN has significant obligations under international law, including international human rights law, and if it does not have primary obligations to behave in a certain way then it cannot be held responsible for a failure to do so. ${ }^{33}$ However, there is no explanation by Klabbers as to why the UN is not bound by customary international law, except a vague reference to the UN's lack of consent to be bound. ${ }^{34}$ It is true as Klabbers states that a bystander cannot be held liable for failing to rescue a drowning child unless it can be established that there is a legal obligation to act and that the individual was in a position to do so. ${ }^{35}$ The UN is in a position to act in the sense of taking preventive and other reasonable measures when it has a military force in a country in a way that it is not able to act in other situations where it has no force on the ground and, although the issue of its legal obligation to act remains contested, ${ }^{36}$ it is argued that it does have such obligations under customary human rights law.

As an international legal person, a status implied from the provisions of the UN Charter indicating the organisation's autonomy from member states, the UN possesses separate rights and duties on the international plane. ${ }^{37}$ More substantively, the International Court of Justice has declared that the UN is a subject of international law and as 'as such' is 'bound by any obligations incumbent upon' it 'under general rules of international law, under their constitutions or under international agreements to which' it is a party. ${ }^{38}$ Verdirame concludes that 'the most plausible interpretation' of the term 'general rules of international law' used by the Court is that it is shorthand 'for customary international law of universal or quasi-universal applicability and for general

33 Jan Klabbers, 'Reflections on Role Responsibility: The Responsibility of International Organizations for Failing to Act', European Journal of International Law, vol. 28, 2017, p. 1136. See also James Crawford, State Responsibility: The General Part (Cambridge: Cambridge University Press, 2013), p. 218.

34 Klabbers, supra note 33, p. 1149. He points to the UNSG's Bulletin on International Humanitarian Law (UN Doc. ST/sGB/1999/13, 6 August 1999) as an example of the UN consenting to some international norms. Rather than finding obligations in the primary rules of international law, Klabbers argues that obligations can be found in the broad mandate of the organisation - Klabbers, supra note 33, pp. 1137-43.

35 Ibid, p. 1150.

36 Frédéric, Mégret and Florian Hoffman, 'The UN as a Human Rights Violator? Some Reflections on the UN's Changing Human Rights Responsibility', Human Rights Quarterly, vol. 25, 2013, p. 314 .

37 Reparations for Injuries Suffered in the Service of the United Nations, Advisory Opinion (1949) ICJ Reports, p. 179.

38 Interpretation of the Agreement of March 1951 between the wHO and Egypt, Advisory Opinion (1980) ICJ Reports, p. 90. 
principles of law'. ${ }^{39}$ However, a strict consensual view of international law at least casts doubt upon the automatic attachment of customary human rights duties to the UN without its subsequent express or tacit consent ${ }^{40}$ although the orthodox position is that unless a state is a persistent objector customary international law is binding on all states, ${ }^{41}$ and this arguably should apply to the UN. Nevertheless, while international legal personality gives the UN the capacity to hold duties and rights, the actual possession of specific obligations including ones of due diligence remains uncertain until the UN internalises these obligations. In general terms, it would be crippling for the legitimacy of the UN for it to deny that it is bound by the external rules of the international order it has helped to create, moreover a legal order that it is at the heart of. As stated by Verdirame, it would be extremely disruptive for the international system to tolerate the presence of actors that are endowed with legal personality, and thus with the legal capacity to operate upon the international plane, but are exempt from a body of universally or almost universally accepted rules.'42

In identifying the applicability of human rights law to peacekeeping operations 'regardless of the character of the situation' to which the force is deployed, the authors of the Leuven Manual identify that the primary source of obligation on the UN when performing its peacekeeping function is found in customary human rights law. ${ }^{43}$ Nevertheless, there remains uncertainty regarding the existence of positive obligations under customary human rights law. John Cerone captures the problem in stating that it is unclear whether the positive treaty obligations in Article 2(1) of the International Covenant on Civil and Political Rights have counterparts in customary international law. However, having said that he accepts the application of such obligations to the UN at least when it is exercising sovereign powers over a territory as it did exceptionally in Kosovo. ${ }^{44}$ Although most modern peacekeeping operations do not exercise a full range of sovereign powers, they do regularly use a lesser range of

39 Guglielmo Verdirame, The UN and Human Rights: Who Guards the Guardians? (Cambridge: Cambridge University Press, 2011) p. 71.

40 Raphael M. Walden, 'The Subjective Element in the Formation of Customary International Law', Israel Law Review, vol. 12, 1977, p. 359.

Anthea Roberts and Sandesh Sivakumaran, 'Theory and Reality of the Sources of International Law', in Malcolm D. Evans (ed), International Law (Oxford: Oxford University Press, $5^{\text {th }}$ edn 2018), p. 96.

42 Verdirame, supra note 39.

43 Gill, Fleck, Boothby and Vanheusden, supra note 7, p. 76-8, 83 .

44 John Cerone, 'Reasonable Measures in Unreasonable Circumstances: A Legal Responsibility Framework for Human Rights Violations in Post-Conflict Territories under UN Administration', in Nigel D. White and Dirk Klaasen (eds), The UN, Human Rights and Post-Conflict Situations (Manchester: Manchester University Press, 2005), p. 59, p. 77. 
public powers (using force to protect civilians and to tackle spoilers, powers of arrest and detention, as well as a range of public order powers). ${ }^{45}$ It is argued here that when performing these functions peacekeeping forces as subsidiary organs of the UN are bound by positive obligations of human rights law, requiring them to exercise due diligence in protecting the human rights of civilians under their authority or within their power. ${ }^{46}$

In summary, due diligence obligations attach to the UN in regards to its peacekeeping operations, either by dint of customary rules of international law applicable to it as an international legal person, or, secondly, as the analysis in the remaining sections show, via its own internal constitutional order and the rules deriving from it. ${ }^{47}$

The Application of Due Diligence to UN Peacekeeping

Outside of Chapter viI resolutions, which arguably now regularly impose due diligence obligations under the UN Charter on peacekeeping operations to take a range of measures to protect the basic human rights of civilians, ${ }^{48} \mathrm{UN}$

45 For discussion of these functions see Gill, Fleck, Boothby and Vanheusden, supra note 7, pp. 150-53, p. 159, p. 176.

46 Ibid, p. 268, p. 273, where the authors of the Leuven Manual state that 'demands for accountability will also be high in situations where Peace Operations directly affect the rights of individuals', and identify that the principle of due diligence operates 'to guarantee the lawfulness' of the activities of peacekeeping forces.

47 Henry G. Schermers and Niels M. Blokker, International Institutional Law (Leiden: Martinus Nijhoff, $5^{\text {th }}$ edn, 2011), p. 755; Marten Zwanenberg, 'Compromise or Commitment? Human Rights and International Humanitarian Law Obligations for UN Peace Forces', Leiden Journal of International Law, vol. 11, 1998, p. 232.

48 For example, the mandate of the UN Mission to South Sudan (UNMISs) states, inter alia, that the Security Council, acting under Chapter vII of the UN Charter, ' 4 . Decides that the mandate of UNMISs shall be as follows, and authorizes UNMISs to use all necessary means to perform the following tasks: (a) Protection of civilians: (i) To protect civilians under threat of physical violence, irrespective of the source of such violence, within its capacity and areas of deployment ...(ii) To deter violence against civilians, including foreign nationals, especially through proactive deployment, active patrolling ... in particular when the Government of the Republic of South Sudan is unable or failing to provide such security; (iii) To implement a mission-wide early warning strategy, including a coordinated approach to information gathering, monitoring, verification, early warning and dissemination, and response mechanisms, including response mechanisms to prepare for further potential attacks on United Nations personnel and facilities; (iv) To maintain public safety and security within and of UNMISs protection of civilians sites; (v) To exercise good offices, confidence-building, and facilitation in support of the mission's protection strategy, especially in regard to women and children ...; (vi) To foster a secure 
doctrine and practice on due diligence do not demonstrate a clear acceptance of external due diligence obligations arising under international human rights law. This is especially so given that there are some instances in peacekeeping practice where due diligence should apply to the UN, but the UN does not appear to accept it has obligations in this regard. The failure to take measures to prevent cholera in Haiti seems to be a breach of a duty of care by the UN and a lack of due diligence to take measures to protect the rights of the population of Haiti. While discussion of Haiti has been largely about the legality and legitimacy of the UN's use of immunity to protect itself from national courts, ${ }^{49}$ the failure to screen or to ensure the screening of the contingent from Nepal and to ensure that proper sanitation was installed in the camp by private contractors engaged by MINUSTAH, ${ }^{50}$ demonstrate that the UN did not achieve the requisite level of care in fulfilling its obligations to respect and protect the life and health of the people of Haiti. Nevertheless, the UN has only accepted 'moral responsibility to the victims of the cholera epidemic in Haiti, ${ }^{51}$ indicating that there is still a long way to go towards the UN fully accepting that it is bound by legal obligations of due diligence.

The UN's ability to protect itself from national courts by invoking its immunity may be called into question in future cases following a recent judgment of the US Supreme Court. InJam v International Finance Corporation (IFC), the US Supreme Court dismissed the IFC's reliance on absolute immunity in the face of a mass claim brought by victims of environmental and health damage caused by the negligent construction of an IFC financed power station in India. The potential impact of this judgment on the UN's continuing reliance on absolute immunity to protect its independence from states is unclear. ${ }^{52}$ Adapting a form of restrictive immunity to the $\mathrm{UN}$ would suggest that, if the Supreme Court's approach takes hold in the jurisprudence of national courts, the UN's claim to immunity in a case like Haiti might not be upheld by those courts. The

environment for the eventual safe and voluntary return of internally-displaced persons (IDPs) and refugees including, where compatible and in strict compliance with the United Nations Human Rights Due Diligence Policy (HRDPP), through monitoring of, ensuring the maintenance of international human rights standards by, and specific operational coordination with the police services in relevant and protection-focused tasks, in order to strengthen protection of civilians' - UN Doc. S/RES/2155, 27 May 2014.

49 Georges $v$ United Nations, US Court of Appeals $2^{\text {nd }}$ Circuit, No. 15-455-cv, 18 August 2016. See article by Yohei Okada in this issue.

5o See Alejando Cravioto, 'Final Report of the Independent Panel of Experts on the Cholera Outbreak in Haiti', 4 May 2011. See contribution of Martina Buscemi in this issue.

51 UN Doc. A/REs/71/161, 13 January 2017. See also UN Secretary General's Report, 'A New Approach to Cholera in Haiti', UN Doc. A/71/620, 25 November 2016.

Jam v International Finance Corporation, 586 U.S. (2019). 
distinction drawn in sovereign immunity claims between sovereign and commercial acts is not automatically applicable to the immunity of the UN..$^{53}$ However, as has been said the UN does exercise public powers in the performance of its peacekeeping functions, for instance the power of detention, ${ }^{54}$ the right to use potentially lethal force, and sometimes lawmaking making powers as in Kosovo. ${ }^{55}$ These should continue to be covered by the organisation's immunity, but in acts outside of that, for example in engaging private contractors to construct sanitation facilities for peacekeepers, the arguments for immunity to protect the UN's ability to perform its functions do not appear convincing. Indeed, the justification for invoking immunity in these circumstances seems to be to prevent crippling damages being awarded against the UN. Nevertheless, the absolute form of immunity seemingly found in the Convention on Privileges and Immunities 1946, Article 2, remains a massive, possibly insurmountable obstacle given the caveats found in the Supreme Court's judgment, ${ }^{56}$ and the UN's consistent invocation of such immunity when faced with mass claims against it.

Despite significant inconsistencies in practice, and the obscuring effect of assertions of immunity by the UN, which even if accepted do not absolve the UN from responsibility, UN peacekeeping doctrine indicates acceptance by the UN that it must take at least some measures to respect and protect human rights. However, the resultant due diligence framework remains quite basic. In particular, the UN's duties towards individuals remain underdeveloped. As a duty bearer the UN's due diligence not only extends to taking measures to ensure that TCNs comply with their human rights obligations to protect the rights of individuals within their jurisdiction, but also means that the UN owes duties

53 Julian Arato, 'Equivalence and Translation: Further thoughts on Io Immunities in Jam v. IFC', EJIL Talk, 11 March 2019.

54 Bruce Oswald, 'Detention by United Nations Peacekeepers: Searching for Definition and Categorisation', Journal of International Peacekeeping, vol. 15, 2011, p. 119.

55 Alexandros Yannis, 'The UN as Government in Kosovo', Global Governance, vol. 10, 2004, p. 67 .

$5^{6}$ Especially the idea that the restrictive approach is only the 'default' rule in the absence of a stronger form of immunity specified by the organisation's own charter or rules such as those contained in the Convention on Privileges and Immunities of the UN 1946 - Chief Justice Roberts in JamvIFC, supra note 62, p. 14. See also the potentially limited nature of the commercial activities of organisations, and the requirement under US law that any commercial activity must have sufficient nexus to United States - Chief Justice Roberts in Jam vIFC, supra note 62, pp. 14-15. On 14 February 2020, on remand of the case from the Supreme Court, the District Court of Columbia revisited the issue and upheld the IFC's immunity, the Court confining itself to examining whether the action has sufficient nexus to the US, which it found it did not - Jam v International Finance Corporation, Case 1:15-cvoo612-JDB Document 61, 14 February 2020. 
of due diligence to the rights holders, namely individuals within its power. In terms of internalising due diligence obligations there is more evidence that the UN is increasingly accepting its due diligence obligations towards TCNs, but is more reluctant to accept that it has due diligence obligations towards individuals in the host state. The UN may contract its peacekeeping function to TCNS, but their soldiers are present in a host state as UN peacekeepers, which means that the UN's duties to ensure that its peacekeepers do not violate human rights cannot stop at the level of UN-TCN relations but must extend in principle to the population of the host state. In practice, those due diligence obligations will only be triggered where the UN has the power to prevent abuse of individuals within the host state's population.

It is worth noting that in its 2018 resolution on 'United Nations Peacekeeping Operations' the Security Council affirmed its support for the 'development of a comprehensive and integrated performance policy framework that identifies clear standards of performance for evaluating all United Nations civilian and uniformed personnel'; while urging that all TCNs 'meet UN performance standards for personnel, training, and equipping. ${ }^{\prime} 7$ There is a drive by the UN to improve peacekeeping performance and management but the question remains as to how that might translate into meaningful due diligence obligations. ${ }^{58}$ It is also questionable whether UN practice is heading towards the implementation of due diligence obligations in a human rights law sense, or whether it is developing a doctrine of due diligence more akin to that used in the business community: 'due diligence is normally understood to mean different things by human rights lawyers and by business people ... human rights lawyers understand due diligence as a standard of conduct required to discharge an obligation, whereas business people normally understand due diligence as a process to manage business risks. ${ }^{59}$ Nevertheless, three tentative examples of emerging institutional practice and their implications for the existence of both primary and secondary rules of due diligence applicable to the $\mathrm{UN}$ are outlined here. ${ }^{60}$

57 UN Doc. S/RES/2436, 21 September 2018, paras. 1 and 3.

$5^{8}$ See, more generally, UNSG Report, 'Shifting the management paradigm in the United Nations: implementing a new management architecture for improved effectiveness and strengthened accountability' UN Doc. A/72/492/Add.2, 21 March 2018, especially paras. 5, $6,63,65,66$ and 105 on risk management and accountability.

59 Jonathan Bonnitcha and Robert McCorquodale, 'The Concept of Due Diligence in the UN Guiding Principles on Human Rights', European Journal of International Law, vol. 28, 2017, p. 900.

6o For a detailed review of UN doctrine and practice see Nigel D. White, 'Due Diligence, the UN and Peacekeeping' in Heike Krieger and Anne Peters (eds), Due Diligence in International Law (Oxford: Oxford University Press, forthcoming 2021). 
The Secretary General's 2003 Bulletin on sexual abuse exhibited some due diligence characteristics in that it was directed at providing measures of protection for individuals from SEA by UN peacekeepers. The Bulletin states that the Head of Mission 'shall be responsible for creating and maintaining an environment that prevents sexual exploitation and sexual abuse, and shall take appropriate measures for this purpose'. In particular, the Head of Mission 'shall inform his or her staff of the contents of the present bulletin'. ${ }^{61}$ Furthermore, the Bulletin provided a limited form of due diligence in relation to third parties but specifically when the UN has entered into arrangements with them, by providing that UN officials shall inform them of the standards of conduct, and 'shall receive a written undertaking from those entities or individuals that they accept these standards'. Furthermore, it stated that the 'failure of those entities or individuals to take preventive measures against sexual exploitation or sexual abuse, to investigate allegations thereof, or to take corrective action when sexual exploitation or sexual abuse has occurred, shall constitute grounds for termination of any cooperative arrangement with the United Nations.' ${ }^{62}$

However, in large part, the 2003 Bulletin restricted appropriate due diligence measures of prevention to informing peacekeepers of the contents of the Bulletin. In terms of remedies, the possibility of referral to national prosecuting authorities, ${ }^{63}$ is insufficient given the normal weaknesses of the host state's criminal justice system and the unwillingness of TCNs to punish offenders. Of further concern are the limited preventive measures to be taken when engaging non-UN entities, which are restricted to duties of informing such entities of the standards, and termination of the arrangements if those entities fail to comply with those standards.

Due to the serious problem of on-going SEA by peacekeepers the UN has increased its preventive measures, particularly in the form of the screening of peacekeepers. ${ }^{64}$ Bearing in mind the introduction of cholera into Haiti by

61 UN Secretariat, 'Special measures for protection from sexual exploitation and sexual abuse', UN Doc. ST/SGB/2003/13, 9 October 2003, section 4 'Duties of Heads of Department, Offices and Missions', para. 4.1.

$62 \quad$ Ibid. section 6.

63 Ibid. section 5 .

64 UN Policy on Human Rights Screening of United Nations Personnel, 11 December 2012 (https://police.un.org/sites/default/files/policy_on_human_rights_screening_of_un_personnel_december_2012.pdf accessed on 7 September 2020). See also UNSG Report, 'Special measures for protection from sexual exploitation and abuse', UN Doc. A/73/744, 14 February 2019; UNSG Report, 'Special measures for protection from sexual exploitation and abuse: a new approach', UN Doc A/71/818, 28 February 2017. As regards UN staff 
peacekeepers, screening should be extended to reduce the risk of peacekeepers being the carriers of disease as well as being the source of human rights abuse (if, for instance, they have criminal convictions for violence as well as sexual abuse), and the UN should exclude contributions from TCNs having poor track records in this regard. There is some uneven practice to support this. For example, in a Resolution adopted in 2016, the Security Council endorsed the Secretary General's decision to repatriate a particular military unit 'where there is credible evidence of widespread or systemic sexual exploitation and abuse'. It also requested that the Secretary General replace all military units of a TCN where allegations have been made of SEA and the TCN had not taken appropriate steps to investigate the allegation, and ensure that replacements met UN standards of conduct. It welcomed the efforts of the Secretary General to expand vetting of all UN peacekeeping personnel to ensure that they do not have a history of sexual misconduct. ${ }^{65}$

None of these initiatives or measures, however, indicate that the UN is prepared to accept responsibility for a failure to prevent SEA by its peacekeepers. Indeed, the UN does not accept liability for the off-duty acts of its peacekeepers. ${ }^{66}$ However, as Athena Nguyen points out: 'conduct such as SEA may not be provided for in the rules of the organisation but this does not necessarily exempt the UN from responsibility' ${ }^{67}$ Furthermore, 'this argument may be even stronger for conduct that is systemic, widespread, and ongoing, as acts of SEA by UN peacekeeping personnel appear to be'.68 Article 8 of ARIO 2011 provides that the ultra vires conduct of an 'organ or agent' is an act of the UN 'if the organ or agent acts in an official capacity and within the overall functions of that organization.69 While this may mean it is difficult to attribute SEA conduct directly to the UN because it is committed in private, the UN remains responsible for its own failure to prevent SEA conduct from being committed by peacekeepers. After examining the ILC's Commentaries on this aspect of the ARIO, Ngyuen states that 'the mere fact that the conduct was undertaken in an off-duty capacity does not necessarily exclude the responsibility of the

members see UNSG's Bulletin, 'Addressing discrimination, harassment, including sexual harassment, and abuse of authority' UN Doc. ST/SG B/2019/8, 10 September 2019, which at para 3.3 lists the 'obligations of heads of entities' to include at (e) 'exercise due diligence by screening job candidates ... during recruitment processes'.

65 UN Doc. S/RES/2272, 11 March 2016.

66 'Memorandum to the Director, Office for Field Operational and External Support Activities' [1986] United Nations Juridical Yearbook 300.

67 Athena M. Nguyen, 'Sexual Exploitation and Abuse on Peacekeeping Operations: Is the United Nations Responsible?', Journal of International Peacekeeping, vol. 19, 2015, p. 166.

68 Ibid.

$69 \quad$ ARIO 2011, Article 8. 
international organisation if the conduct breached an obligation of prevention that may exist under international law' ${ }^{70}$ Nguyen concludes that the UN 'may still bear responsibility for the conduct of its peacekeeping personnel if the "off-duty" misconduct breached the UN's positive obligations to prevent this misconduct'.71 However, as Ferstman relates, UN practice has fallen considerably short of this: 'the UN does not see itself as having any obligation to entertain claims concerning its own liability for sexual exploitation and abuse allegations which occur under its watch; instead, it has carved out a much more limited role for itself - supporting efforts of troop contributing countries to investigate and prosecute criminal allegations and encouraging states to address paternity and child support claims, and to explore the possible use of $e x$ gratia payments to victims. ${ }^{72}$ In other words the UN has taken some tentative steps to recognising that it has due diligence obligations in its relations with TCNs, but not so in relation to victims of peacekeeping SEA.

\section{The Protection of Civilians}

At a general level the UN's due diligence obligations to ensure respect for human rights by peacekeepers include the adoption of measures such as clear rules, training, education, risk assessment and mitigation, but also to ensure a peacekeeping force has adequate resources and the capabilities to fulfil its mandate. ${ }^{73}$ More specifically, the ambit of due diligence extends to require that the UN puts in place reasonable measures to ensure that peacekeepers actively protect the human rights of civilians in their areas of deployment from violation by non-UN actors. Such measures, scattered unevenly and not

$70 \quad$ Nguyen, supra note 67.

71 Ibid. See further Carla Ferstman, 'Reparations for Mass Torts Involving the United Nations: Misguided Exceptionalism in Peacekeeping Operations', International Organizations Law Review, vol. 16, 2019, p. 57. See also the Trust Fund in Support of Victims of Sexual Exploitation and Abuse, as indicated in UNSG Report, 'Special measures for protection from sexual exploitation and sexual abuse', UN Doc. A/69/779, 13 February 2015. The Trust Fund supports UN and non-UN entities and organisations that provide victim assistance and support services (but not victim compensation) in accordance with the United Nations Comprehensive Strategy on Assistance and Support to Victims of Sexual Exploitation and Abuse by United Nations Staff and Related Personnel, annexed to UN Doc. A/REs/62/214, 21 December 2007.

72 Ferstman, supra note 71 , pp. $5^{8-9}$.

73 Nigel D. White, 'The Use of Weapons in Peace Operations' in Stuart Casey-Maslen (ed), Weapons under International Human Rights Law (Cambridge: Cambridge University Press, 2014) pp. 228-38. 
always convincingly in UN doctrine (for example in Security Council Resolutions, the Brahimi Report, Capstone Doctrine, and the Report of the High Level Independent Panel on Peace Operations), include proactive patrolling, rapid redeployment, adequately protected safe havens, intercessions, detention of individuals on security grounds, and the use of potentially lethal force where absolutely necessary to protect the lives of civilians and peacekeepers. ${ }^{74}$

A detailed analysis of key UN documents to uncover indications of whether these measures could be said to flow from duties of due diligence has been undertaken elsewhere..$^{75}$ The purpose here is to try to understand whether it is possible to identify a due diligence obligation on the UN to protect civilians, and to consider the implications of a failure to fulfil that obligation. According to Willmot and Sheeran the 'most important rights' for the protection of civilians in peacekeeping 'include the right to life, the prohibition against torture and ill-treatment, and the freedom from arbitrary detention'. However, in terms of the duty bearer, Willmot and Sheeran point to the host state as the main actor when stating that ' $[\mathrm{t}$ ] hese are human rights that any host state will have an obligation to respect and ensure respect for (that is, a positive obligation), including by non-state actors. ${ }^{76}$ They concede that the application of human rights law 'to UN peacekeeping operations is difficult to contest', although they state that 'the precise content of these obligations' is unclear: ' $[\mathrm{t}]$ he UN is not party to human rights treaties and the greatest difficulty lies in understanding the scope and extent of obligations for a UN force, which has no sovereignty over a territory and has lesser powers than a state. 77

However, this understates the growth in public powers exercised by the UN in its modern stabilisation-type peace operations. ${ }^{78}$ As Alexander Guilder has written such forces 'are mandated to support the extension of state authority';

74 See Security Council resolutions on the Protection of Civilians, starting with UN Doc. S/RES/1265, 17 September, 1999 and most recently UN Doc. S/RES/2474, 11 June 2019 ; Report of the Panel on United Nations Peace Operations (Brahimi Report), UN Doc A/55/305-S/200o/809, 21 August 2000, paras. 62-3; UnDPKo, 'Capstone Doctrine: United Nations Peacekeeping Operations: Principles and Guidelines', 18 January 2008, pp. 23-7; Report of the High Level Independent Panel on Peace Operations on Uniting our Strengths for Peace: Politics, Partnership and People, UN Doc. A/70/95-S/2015/446, 2015 (HIPpo Report), 16 June 2015, paras. 87, 88, 91, 95, 213, 232, 264, 265, 289.

75 White, supra note 60.

76 Heidi Willmot and Scott Sheeran, 'The Protection of Civilians Mandate in UN Peacekeeping Operations: Reconciling Protection Concepts and Practices', International Review of the Red Cross, vol. 95, 2013, p. 526 .

77 Ibid, p. 527 .

78 UN Organization Stabilization Mission in the DR Congo (MONUsco); UN Multidimensional Integrated Stabilization Mission in the Central African Republic (MINUSCA); UN Multidimensional Integrated Stabilization Mission in Mali (MINUSMA). 
'they operate alongside state forces and actively build the capacity of those forces'; 'they use varying degrees of proactive, robust force to prevent attacks on themselves and those they are mandated to protect'; and 'lastly, they have mandates to support (re)establishing the rule of law' ${ }^{79}$ More specifically such forces exercise powers of arrest, detention and regularly use potentially lethal force, ${ }^{80}$ which can cross the threshold into the sort of protracted armed violence that triggers the application of international humanitarian law to such forces. ${ }^{81}$ In such conditions of violence, Willmot and Sheeran identify a potential positive or due diligence obligation on the UN 'to ensure respect' for international human rights law 'by others such as non-state actors, private individuals and even local authorities'. 82 This signifies that 'a failure to intervene may also violate' the human rights obligations 'owed by UN peacekeepers to the host state's population' ${ }^{83}$ In the extreme instance of the loss of life at Srebrenica, the victims' families succeeded in a claim against the troop sending state of the peacekeepers (The Netherlands), ${ }^{84}$ the UN being protected from liability by its immunity before national courts. ${ }^{85}$ However, the Netherlands' Supreme Court ultimately decided that the liability of the Netherlands was for the conduct of peacekeepers under the effective control of the state rather than the failure to take measures to prevent genocide. ${ }^{86}$ In this way, the Court managed to restrict the Netherlands' liability to $10 \%,{ }^{87}$ when the adoption of a

79 Alexander Gilder, "The Effect of "Stabilization" in the Mandates and Practice of UN Peace Operations', Netherlands International Law Review, vol. 66, 2019, p. 51.

$80 \quad$ Bruce 'Ossie' Oswald, 'Detention by United Nations Peacekeepers: Searching for Definition and Categorisation', Journal of International Peacekeeping, vol. 15, 2011, p. 130.

81 UNSG, Observance by United Nations forces of international humanitarian law, UN Doc. ST/SG B/1999/13, 6 August 1999.

82 Willmot and Sheeran, supra note 76, p. 527 .

$83 \quad$ Ibid. p. 537.

84 Cedric Ryngaert and Otto Spijkers, "The End of the Road: State Liability for Acts of UN Peacekeeping Contingents After the Dutch Supreme Court's Judgment in Mothers of Srebrenica', Netherlands International Law Review, vol. 66, 2019, p. 538.

85 Stichting Mothers of Srebrenica and Others $v$ The Netherlands, Decision of the European Court of Human Rights, Application No 65541/12, 11 June 2013.

86 Stichting Mothers of Srebrenica et al $v$ the State of the Netherlands and the United Nations, Netherlands Supreme Court, Case No 17/04567, 19 July 2019, paras. 3.5.2-3.5.3. As Tom Dannenbaum states: '[t]his is a step backwards. The power-to-prevent standard ... recognizes the levers of control retained by the state in peacekeeping operations (troop selection and promotion, training, disciplinary authority, and criminal jurisdiction) as necessarily relevant to the attribution of wrongful conduct by its troops' - 'A Disappointing End of the Road for the Mothers of Srebrenica Litigation in the Netherlands', EJIL Talk. 23 July 2019.

$87 \quad$ Stichting Mothers of Srebrenica (Netherlands Supreme Court), supra note 96, para. 6. For a fuller discussion of this case see the contribution of Yohei Okada in this issue. 
due diligence standard would have suggested a greater proportion, moreover that such responsibility should be shared with the UN.

\section{The UN's Due Diligence Policy of 2013 and Non-UN Forces}

The UN's Due Diligence Policy of $2013,{ }^{88}$ in which the UN undertakes to implement measures to ensure that non-UN forces it supports are not committing war crimes, is a step forward in the sense that it expressly recognises due diligence can be applicable to the UN. The Policy expressly accepts the UN's due diligence obligations in relation to non-UN forces, but arguably it also opens the door to more general positive obligations to take measures to prevent and respond to violations by third parties by accepting the applicability of human rights law, international humanitarian law and refugee law to the UN. ${ }^{89}$ The wider import of the Policy is found in the statement that: '[a]dherence to the human rights due diligence policy is important to maintain the legitimacy, credibility and public image of the United Nations and to ensure compliance with the Charter and with the Organization's obligations under international law' 90

The Policy accepts that the UN must take precautions to assess the risk of violation and respond to violations by non-UN forces it supports, including intercession with the entity in question and if necessary the removal of support. Specifically when the UN is contemplating involvement with non-UN security forces it 'must therefore pursue a policy of due diligence' consisting of: an assessment of 'the risk of the recipient entity committing grave violations of international humanitarian law, human rights law or refugee law'; 'transparency with receiving entities about the legal obligations binding the Organization and the core principles governing provision of support'; and an 'effective implementation framework' including procedures for monitoring compliance and interceding. ${ }^{91}$

Standing alone this represents a positive and explicit development towards accepting that the UN has human rights due diligence obligations to take a series of precautionary, preventive and responsive measures to ensure that a state or non-state security actor working alongside UN peacekeepers does not commit grave violations of human rights or other international norms. This

88 'Human rights due diligence policy on United Nations support to non-United Nations security forces', UN Doc. A/67/775-S/2013/110, 5 March 2013.

$89 \quad$ Ibid. para. 1.

9o Ibid. para. 3 .

$91 \quad$ Ibid. para. 2. 
Policy establishes that the UN owes due diligence obligations in its relationships with non-UN security actors. However, its adoption by the UN raises the question of the UN's wider due diligence obligations to the host population to take positive measures through its peacekeepers to address potential or actual abusive actions committed by any violent non-UN actor who operates in areas to which peacekeepers are deployed.

\section{9}

\section{Conclusion}

This contribution has focused on the application, acceptance, and implementation of human rights due diligence obligations in UN peacekeeping operations. It has concentrated on identifying the applicability of primary rules of due diligence to the UN. This article has pointed to growing evidence of the development of standards and measures by the UN that would fit the meaning and purpose of due diligence, although there are very few instances of due diligence expressly being used as a term within the UN. This is not to say that such obligations are not applicable to the UN. It has been argued that due diligence obligations are applicable either through customary human rights law, or the internal law of the UN, or both. The development of measures such as screening peacekeepers, blacklisting TCNs with poor track records in preventing and/ or punishing perpetrators of SEA, are designed to prevent peacekeepers from doing harm. ${ }^{92}$

As well as measures to prevent abuse by peacekeepers, the contribution has identified a number of positive measures in UN peacekeeping practice designed to reduce loss of civilian life or other serious human rights violations of the host state's population including: proactive patrolling, weapons training, temporary and reviewable preventive detention, protection of UN compounds and camps, the identification of threats and risks and strategies to address these, including addressing the 'risk averse' approach of many TCNs. ${ }^{93}$

Responsibility for human rights violations caused by the failure to adopt and carry out these measures should be shared between the TCNs and the $\mathrm{UN},{ }^{94}$ and oversight should be secured by an independent review process

92 Rosa Freedman, 'UNaccountable: A New Approach to Peacekeepers and Sexual Abuse', 29 European Journal of International Law, vol. 29, 2018, p. 963.

93 Cruz Report, 'Improving Security of United Nations Peacekeepers: We need to change the way we are doing business', 19 December 2017, p. 5.

94 The current UNSG's Action for Peacekeeping initiative, the Declaration of Shared Commitments on UN Peacekeeping Operations signed up to by member states on 16 August 2018, contains a collective commitment 'to ensuring the highest level of peacekeeping 
tasked with reviewing and developing standards and positive measures to secure them. This review process should lead to the recommendation of standards, measures, changes, and remedies where peacekeeping forces have manifestly failed to fulfil their obligations of due diligence. Such standards, measures and mechanisms should be gathered together and included in a new UN Secretary General's Bulletin on measures to protect human rights in peacekeeping operations. ${ }^{95}$

In developing an accountability framework, ${ }^{96}$ it will be necessary to understand the role of secondary rules in engaging the liability of the UN for failing to exercise due diligence. Article 4 of the ARIO specifies that there is an internationally wrongful act when 'conduct consisting of an act or omission' is attributable to the organisation and constitutes a breach of an obligation owed by the organisation. The inclusion of 'omission' is a secondary rule which supports the primary rules of due diligence. In other words there are primary rules of due diligence incumbent on the UN, for example to take measures through its peacekeeping operations to prevent human rights abuses, so that the UN's failure to act i.e. its failure to take such measures, constitutes an internationally wrongful omission that can give rise to responsibility under the secondary rules of international law. In terms of attribution, while there may well not be sufficient control exerted by the UN over peacekeeping acts to engage Article 7 of ARIO, the failure to take measures is an omission by a subsidiary organ of the UN, and therefore engages Article 6 of ARIO. ${ }^{97}$

The development of a coherent and consistent concept of due diligence for UN peacekeeping would involve the identification and enhancement of the UN's institutional due diligence obligations, for example through consistent Security Council decision-making, and by the adoption of clear procedural due diligence obligations such as human rights risk assessment by the UN Secretariat. There is admittedly limited and uneven evidence of emerging standards in this regard, as well as a growing sense that the UN has to exercise a certain amount of due diligence as regards TCNs and non-UN security forces it supports. However, the approach taken in this contribution considers the

performance, and to hold all civilian and uniformed peacekeepers, particularly leadership, accountable for effective performance under common parameters while addressing performance shortfalls. The Secretary-General commits to develop an integrated performance policy framework based on clear standards for all actors' (https://peacekeeping .un.org/en/action-for-peacekeeping-a4p accessed 7 September 2020).

96 For a fuller understanding of accountability, especially non-judicial forms, see the contribution of Norihito Samata in this issue. 
substantive positive human rights obligations the UN owes to rights holders especially civilians within the host state, and identifies the measures that can reasonably be taken by the UN and its peacekeepers to ensure those rights are protected given the inherent limitations in the way forces are structured. Only by starting with the rights of vulnerable people can a human rights law approach to the due diligence obligations of the UN be realised. Put simply, when the UN promises to protect civilians in countries to which it deploys peacekeepers it needs to take care to ensure that this happens. As stated in the Brahimi Report 2000, with reference to the failure of peacekeeping in Rwanda: 'peacekeepers - troops or police - who witness violence against civilians should be presumed to be authorised to stop it, within their means, in support of basic United Nations principles and ... consistent with the "perception and the expectation of protection created by [an operation's] very presence"'.98

98 Brahimi Report, supra note 74, para. 62, citing the Report of the Independent Inquiry on Rwanda UN Doc. S/1999/1257, 15 December 1999, p. 51. 